\title{
Demographic and socio-economic factors related to food intake and adherence to nutritional recommendations in a cohort of pre-school children
}

\author{
Lise Dubois ${ }^{1, *}$, Anna Farmer ${ }^{2}$, Manon Girard ${ }^{1}$, Daniel Burnier ${ }^{1}$ and Marion Porcherie ${ }^{1}$ \\ 'Department of Epidemiology and Community Medicine, Faculty of Medicine, Institute of Population Health, \\ University of Ottawa, 1 Stewart Street, Office 303, Ottawa, Ontario K1N 6N5, Canada: ${ }^{2}$ Department of \\ Agricultural, Food and Nutritional Science and the Centre for Health Promotion Studies, University of Alberta, \\ Edmonton, Alberta, Canada
}

Submitted 16 March 2010: Accepted 8 December 2010: First published online 10 February 2011

\begin{abstract}
Objective: To examine: (i) children's food intake and adherence to both Canada's Food Guide for Healthy Eating and Dietary Reference Intakes; and (ii) the social and demographic factors related to children's food intake.

Design: A cross-sectional study.

Setting: Data were obtained through the Quebec Longitudinal Study of Child Development 1998-2010, a representative sample ( $n$ 2103) of children born in 1998 in the province of Quebec, Canada. Information on energy, macronutrient and food consumption was derived from responses to a $24 \mathrm{~h}$ dietary recall interview addressed to children's mothers and day-care staff when the children were 4 years old.

Subjects: A total of 1549 children aged 4 years who participated in a nutritional sub-study.

Results: The mean daily total energy intake was $6360 \mathrm{~kJ}(1520 \mathrm{kcal})$ for girls and $6916 \mathrm{~kJ}$ ( $1653 \mathrm{kcal})$ for boys. For boys and girls alike, energy intake was comprised of approximately $54 \%$ carbohydrates, $31 \%$ fats and $15 \%$ proteins. The mean number of servings consumed from each of the four essential food groups closely approached the dietary recommendations made by Canada's Food Guide for Healthy Eating; however, $<2 \%$ of the children in the present study actually met the full dietary guidelines. The dietary intake of pre-school children was associated with socioeconomic and demographic factors, most notably mother's level of education, mother's immigrant status and sex of the child.

Conclusions: Diet-related disparities associated with socio-economic and demographic factors exist from as early as 4 years of age.
\end{abstract}

\author{
Keywords \\ Food intake \\ Nutritional recommendations \\ Socio-economic factors
}

Income is only one among many factors affecting the extent and nature of food purchases ${ }^{(1)}$. Social, cultural and family dynamics all exert an influence on the contents of a given household's shopping basket ${ }^{(2)}$. Consumer behaviours, tastes and adherence to nutritional recommendations are socially shaped, and are an object of social distinction ${ }^{(3,4)}$. Disparities in food consumption are also observed in childhood ${ }^{(5,6)}$. National nutrition surveys such as the Continuing Survey of Food Intakes by Individuals (CSFII) ${ }^{(7)}$ and the National Health and Nutrition Examination Survey $(\mathrm{NHANES})^{(8)}$ have shown that children and adolescents are consuming products high in sugar and fat, and low in nutrient value ${ }^{(9,10)}$. It is also reported that children and adolescents rarely meet nutritional recommendations for intakes of fruit, vegetables and whole-grain products ${ }^{(11,12)}$. In their review of the literature on fruit and vegetable intakes among children and adolescents aged 6-18 years, Rasmussen et al. ${ }^{(13)}$ reported that gender, age, socio-economic position, preferences, parental intake and home availability/accessibility were the determinants supported by the greatest amount of evidence. Regarding ethnicity, studies showed lower fat intakes in immigrants from South Asian countries in comparison with populations born in the $\mathrm{USA}^{(14,15)}$. Most studies also support the idea that high parental education is positively associated with a higher intake of healthy foods ${ }^{(5,16,17)}$. However, it is unclear whether these associations also play a role in influencing the dietary intakes of younger children. Kranz and Siega$\mathrm{Riz}^{(18)}$ reported an inverse relationship between mother's education and the intake of added sugars in pre-school children. When analysing the diet of $>10000$ children aged 3 years from the Avon Longitudinal Study of Pregnancy and Childhood (ALSPAC), North and Emmett ${ }^{(19)}$ 
showed that children's junk food intake was significantly associated with having a younger, less-educated mother and a mother of lower social class. As only a few studies have examined dietary adequacy in pre-school children ${ }^{(20)}$, and even fewer have investigated the socio-economic determinants of healthy eating for this age group, the present study contributes to an area that is not well understood. Hence, the aim of the present paper is to examine the social and demographic factors related to children's food intakes and dietary adherence to both Canada's Food Guide to Healthy Eating (1992-2007) and Dietary Reference Intakes (DRI) ${ }^{(21)}$ in use at the time of the present study.

\section{Methods}

The analyses were performed using data from the Quebec Longitudinal Study of Child Development (QLSCD) 1998-2010, conducted by Santé Québec, a division of the Institut de la Statistique du Québec (ISQ) in Canada ${ }^{(22,23)}$. The QLSCD was established to examine the role of familial and social factors on children's health, as well as on their cognitive and behavioural development. It followed a representative sample ( $n$ 2103) of children born in 1998 in the province of Quebec, Canada. The representative sample was chosen by a random selection of children born throughout the year in each public health geographical area of the province, thus minimizing the effect of seasonality and ensuring geographical representation. Twins and children with major diseases or handicaps at birth were excluded from the study. The children were selected from the master birth register and were first examined at 5 months of age (gestational age adjusted for preterm birth) and subsequently at 1-year intervals.

Of the 2103 infants included in the first cycle of the study, 1944 were still part of the survey in 2002. Of this group, 1549 participated in the nutrition evaluation phase of the study. The age of the children included in the present study varied from 44 to 56 months, with a mean age of 49 (SD 3.12) months. Energy, macronutrient and food consumption levels were derived from a $24 \mathrm{~h}$ multiple-pass dietary recall interview administered by trained nutritionists in children's homes ${ }^{(24)}$. Caregivers were asked to indicate the foods (e.g. type, quantity and recipes) consumed during the $24 \mathrm{~h}$ period preceding the interview. For children attending day care ( $n$ 390), trained nutritionists went to their home and also queried day-care kitchen staff regarding the child's food intake (e.g. time, meal and quantity) for the same $24 \mathrm{~h}$ period. To assess for interand intra-child variability in the consumption of energy and macronutrients (carbohydrates, protein and fats), a second $24 \mathrm{~h}$ dietary recall was administered to $50 \%$ of the sample. All statistical analyses were conducted using adjusted data with results based on usual food consumption patterns and not solely on a single-day recall. A two-step procedure was used: first, a normalizing transformation; and second, a linear transformation that provides a distribution of intakes without the intra-individual component ${ }^{(24,25)}$. The $24 \mathrm{~h}$ recalls were administered evenly across all days in the week. Energy and macronutrient consumption levels, along with servings of food for each meal and for each child, were evaluated according to the Canadian Nutrient File ${ }^{(26)}$ and the US Department of Agriculture (USDA) recipe file ${ }^{(27)}$, which calculate usual consumption levels of food in accordance with Canada's Food Guide to Healthy Eating. Dietary data were managed using a validated nutrient analysis software developed by Micro Gesta (version 73.0, Quebec, Canada) specifically for Canadian nutritional studies.

On the basis of the results of a literature review, different factors that may relate to the quality of children's diet were selected to examine their role as potential determinants. Family type (single-parent family or not), household annual income (<\$CAN20 000, \$CAN20 000-39999, \$CAN40 000-59999 and $\geq \$ C A N 60000$ ), income level (sufficient, insufficient and very insufficient*), mother's education (no high-school diploma, high-school diploma, college diploma and university degree), mother's age group $(<25,25-29,30-34$ and $\geq 35$ years) and immigrant status (immigrant or not) were included in the analyses. Other variables such as mother's BMI (from self-reported weight and height), number of overweight/obese parents and sex of the child were also included. Children's level of physical activity and their energy intake were used as control variables. The degree of children's physical activity was measured through one survey question that asked mothers: 'In your opinion, is your child's level of physical activity less than or more than children of the same age and same sex?' Mothers were asked to respond with one of the following categories: 'much higher', 'slightly higher', 'equal', 'slightly less', 'much less than' and 'do not know'. To examine children's dietary adherence to nutritional recommendations, children's food intakes were compared with both Canada's Food Guide to Healthy Eating (1992-2007) and DRI ${ }^{(21)}$. In correspondence with current American dietary guidelinest, Canada's Food Guide to Healthy Eating in place at the time of the present study recommended the consumption of 5-10 servings of vegetables and fruit, $5-12$ servings of grain products, $2-4$ servings of milk and alternatives and $2-3$ servings of meat and alternatives per day.

Data were weighted by a factor based on the inverse of the selection probability, the probability of non-response and the post-stratification and attrition rates; this ensured

\footnotetext{
* Families are classified as having 'sufficient income' when the household income is above the low-income threshold determined by Statistics Canada (2006). When income is between $60 \%$ and $90 \%$ of the low-income threshold, households are classified as having 'insufficient income'; income levels $<60 \%$ of the low-income threshold are considered as 'very insufficient'. Statistics Canada (2006), Low Income Cut-offs for 2005 and Low Income Measures for 2004, catalogue no. 75F0002MIE, vol. 4.

† Dietary Guidelines for Americans. http://www.cnpp.usda.gov/ Publications/DietaryGuidelines/2005/2005DGPolicyDocument.pdf
} 
that data were longitudinally representative of the infants born in 1998 in the population ${ }^{(28)}$. To correct for response bias, the weights provided by ISQ were used. The rates obtained through the present study are therefore comparable to those of other surveys on the same population that use weighted responses, independent of the distribution of the sample ${ }^{(24)}$. Preliminary analyses indicated that children participating in the nutrition study ( $n$ 1549) were representative of not only infants born in 1998 in the province of Quebec but also of children of the same age ( 4 years) in the Quebec population. Statistical analyses were based on individuals with no missing values for any of the studied variables. Of the 1549 children, 1522 (98\% of the sample) were part of the analyses. The impact of missing data was analysed by conducting with-andwithout analyses. Given that missing data did not impact the results, children with missing data were excluded from the analyses.

Statistical analyses were conducted using the SAS statistical software package version $8 \cdot 2$ (SAS Institute Inc., Cary, NC, USA). Pairwise mean comparisons were verified using a one-way ANOVA and Tukey's adjustment of $P$ values. Food servings, in categories, were compared using the $\chi^{2}$ test of association. Adjusted OR as well as their CI were estimated using logistic regression. In the multivariate regression analyses (Tables 2 and 3), sociodemographic variables were selected from the univariate analyses (Table 1) on the basis of their level of significance in relation to the outcome variables. Significance level was set at $5 \%$.

\section{Results}

Table 1 presents the association between different factors and dietary consumption in terms of energy, macronutrient and food group servings with respect to recommendations made by Canada's Food Guide to Healthy Eating for the studied population. Children's mean daily total energy intake was $6644 \mathrm{~kJ}(1588 \mathrm{kcal}) / \mathrm{d}$. For boys and girls alike, energy intake was comprised of approximately 54\% carbohydrates, $31 \%$ fats and $15 \%$ proteins. Boys $(P<0 \cdot 0001)$, children of immigrant mothers $(P=$ $0 \cdot 005)$, those living in single-parent families $(P=0 \cdot 01)$ and those from families with very insufficient income $(P=0 \cdot 01)$ consumed more energy than did other children. In terms of food group servings, children consumed a mean of 3.5 servings of fruit and vegetables, 4 servings of grain products, 2 servings of milk products and 2 servings of meat and alternatives per day (data not presented). Only $17 \%$ of children consumed the recommended $\geq 5$ servings of fruit and vegetables or grain products per day. Half $(47 \cdot 7 \%)$ of the children consumed the recommended 2 servings of milk products per day, whereas $39 \%$ of children consumed the recommended 2 servings of meat and alternatives per day. The consumption of vegetables and fruit was associated with sex of the child $(P=0 \cdot 03)$, mother's immigrant status $(P=0 \cdot 04)$ and education $(P \leq 0 \cdot 0001)$, household annual income $(P=0 \cdot 0009)$ and mother's BMI $(P=0 \cdot 004)$, whereas the consumption of grain products was associated with sex of the child $(P \leq 0 \cdot 0001)$, mother's immigrant status $(P \leq 0 \cdot 0001)$, single parenting $(P=0 \cdot 01)$ and family income $(P=0 \cdot 02)$. The consumption of milk products was associated with family income $(P=0 \cdot 01)$ and the consumption of meat and alternatives was associated with sex of the child $(P \leq 0 \cdot 0001)$ and single parenting $(P=0 \cdot 02)$.

The adjusted means for energy intake and macronutrient consumption are presented in Table 2. Boys consumed more energy than did girls $(P<0 \cdot 0001)$, and children of immigrant mothers consumed more energy than did children of non-immigrant mothers $(P<0 \cdot 0001)$, independently of children's level of physical activity. The proportion of fat consumed was higher in children from non-immigrant mothers $(P=0 \cdot 04)$ and in children from mothers with no high-school diploma $(P<0 \cdot 0001)$. The proportion of energy intake derived from protein was higher in children of immigrant mothers $(P=0 \cdot 01)$ and in children of more highly educated mothers $(P<0 \cdot 0001)$.

The adjusted OR for consuming $\geq 5$ servings of vegetables and fruit per day was $2 \cdot 2$ in children of non-immigrant mothers, in comparison with children of immigrant mothers $(P=0.002)$, and was as high as 8.5 in children of mothers with a university diploma in comparison with children of mothers with no high-school diploma $(P<0 \cdot 0001$; Table 3$)$. The adjusted OR for consuming $\geq 5$ servings of grain products per day was 5.0 in boys, in comparison with girls $(P<0 \cdot 0001)$, and 0.4 in children of non-immigrant mothers, in comparison with children of immigrant mothers $(P<0 \cdot 0001)$. The adjusted OR of consuming $\geq 2$ servings of milk products per day was 0.7 in boys in comparison with girls $(P=0.003)$, and 1.5 in children of mothers with a university diploma, in comparison with children of mothers with no high-school diploma $(P=0 \cdot 03)$. The adjusted OR of consuming $\geq 2$ servings of milk products per day in children living in households with insufficient or very insufficient income was $0 \cdot 6$, in comparison with children living in households with sufficient income ( $P=0 \cdot 0009)$. The adjusted OR for consuming $\geq 2$ servings of meat and alternatives per day was 1.9 for boys, in comparison with girls $(P<0 \cdot 0001)$.

\section{Discussion}

The present study found that children consumed macronutrients in the proportions recommended by Canadian dietary guidelines, which suggest that $45-65 \%$ of energy intake should be derived from carbohydrates, 25-35\% from fats and $10-30 \%$ from proteins ${ }^{(29)}$. With regard to daily total energy intake, it is difficult to determine whether the levels reported in the present study are well adapted 
Table 1 Mean energy and macronutrient intakes and the prevalence of children attaining the dietary recommendations for four food groups by different characteristics in 4-year-old children from the province of Quebec (from $24 \mathrm{~h}$ dietary recall)

\begin{tabular}{|c|c|c|c|c|c|c|c|c|c|c|c|c|}
\hline \multirow[b]{2}{*}{ Characteristic } & \multicolumn{2}{|c|}{ Energy } & \multicolumn{2}{|c|}{ Carbohydrates } & \multicolumn{2}{|c|}{ Total fats } & \multicolumn{2}{|c|}{ Proteins } & \multirow{2}{*}{$\frac{\text { Fruit and vegetables }}{\geq 5 \text { servings }}$} & \multirow{2}{*}{$\frac{\text { Grain products }}{\geq 5 \text { servings }}$} & \multirow{2}{*}{$\frac{\text { Milk products }}{\geq 2 \text { servings }}$} & \multirow{2}{*}{$\frac{\text { Meat and alternatives }}{\geq 2 \text { servings }}$} \\
\hline & kcal & SD & $\% \mathrm{E}$ & SD & $\% \mathrm{E}$ & SD & $\% \mathrm{E}$ & SD & & & & \\
\hline Total & 1588 & 7 & $53 \cdot 8$ & $0 \cdot 1$ & $31 \cdot 4$ & $0 \cdot 1$ & $14 \cdot 5$ & $0 \cdot 1$ & $16 \cdot 6$ & $16 \cdot 8$ & $47 \cdot 7$ & $39 \cdot 1$ \\
\hline \multicolumn{13}{|l|}{ Child's sex } \\
\hline Girl & $1520^{*}$ & 10 & $53 \cdot 8$ & $0 \cdot 1$ & $31 \cdot 4$ & $0 \cdot 1$ & $14 \cdot 5$ & $0 \cdot 1$ & $14 \cdot 5^{*}$ & $7 \cdot 0^{*}$ & $46 \cdot 7$ & $28 \cdot 2^{*}$ \\
\hline Boy & 1653 & 9 & $53 \cdot 8$ & $0 \cdot 1$ & $31 \cdot 4$ & $0 \cdot 1$ & $14 \cdot 5$ & $0 \cdot 1$ & $18 \cdot 6$ & $26 \cdot 3$ & $48 \cdot 6$ & $49 \cdot 6$ \\
\hline \multicolumn{13}{|l|}{ Mother's age (years) } \\
\hline$<25$ & 1613 & 26 & $53 \cdot 3$ & 0.3 & $31 \cdot 9$ & 0.2 & $14 \cdot 4$ & $0 \cdot 2$ & $13 \cdot 9$ & $20 \cdot 7$ & $47 \cdot 9$ & $43 \cdot 5$ \\
\hline $25-29$ & 1612 & 14 & $54 \cdot 0$ & $0 \cdot 2$ & $31 \cdot 3$ & $0 \cdot 1$ & $14 \cdot 3$ & $0 \cdot 1$ & $14 \cdot 1$ & $16 \cdot 2$ & $44 \cdot 5$ & $40 \cdot 2$ \\
\hline $30-34$ & 1575 & 12 & $53 \cdot 8$ & $0 \cdot 2$ & $31 \cdot 4$ & $0 \cdot 1$ & $14 \cdot 5$ & $0 \cdot 1$ & $19 \cdot 9$ & $15 \cdot 7$ & $46 \cdot 4$ & $37 \cdot 6$ \\
\hline$\geq 35$ & 1579 & 11 & $53 \cdot 7$ & $0 \cdot 1$ & $31 \cdot 3$ & $0 \cdot 1$ & $14 \cdot 7$ & $0 \cdot 1$ & $16 \cdot 1$ & $17 \cdot 2$ & $50 \cdot 8$ & $39 \cdot 5$ \\
\hline \multicolumn{13}{|l|}{ Mother's immigrant status } \\
\hline Not immigrant & $1579^{*}$ & 7 & $53 \cdot 8$ & $0 \cdot 1$ & $31 \cdot 5^{\star}$ & $0 \cdot 1$ & $14 \cdot 5^{\star}$ & $0 \cdot 1$ & $17 \cdot 5^{\star}$ & $14 \cdot 4^{*}$ & $47 \cdot 0$ & 38.9 \\
\hline Immigrant & 1635 & 19 & $54 \cdot 0$ & $0 \cdot 2$ & $30 \cdot 9$ & $0 \cdot 2$ & $14 \cdot 8$ & $0 \cdot 1$ & $11 \cdot 8$ & $31 \cdot 1$ & $53 \cdot 1$ & $41 \cdot 4$ \\
\hline \multicolumn{13}{|l|}{ Mother's education } \\
\hline No high-school diploma & 1622 & 17 & $53 \cdot 7$ & $0 \cdot 2$ & $31 \cdot 8^{*}$ & $0 \cdot 2$ & $14 \cdot 0^{\star}$ & $0 \cdot 1$ & $7 \cdot 7^{\star}$ & $17 \cdot 1$ & $41 \cdot 8$ & $37 \cdot 7$ \\
\hline High-school diploma & 1575 & 15 & $53 \cdot 9$ & 0.2 & $31 \cdot 4$ & $0 \cdot \overline{1}$ & $14 \cdot 4$ & $0 \cdot 1$ & $11 \cdot 4$ & $15 \cdot 4$ & $46 \cdot 3$ & $39 \cdot 0$ \\
\hline College diploma & 1581 & 12 & $53 \cdot 7$ & 0.2 & $31 \cdot 4$ & $0 \cdot 1$ & $14 \cdot 6$ & $0 \cdot 1$ & $14 \cdot 1$ & $17 \cdot 9$ & $50 \cdot 0$ & $39 \cdot 4$ \\
\hline University diploma & 1586 & 13 & $53 \cdot 8$ & $0 \cdot 2$ & $31 \cdot 2$ & $0 \cdot 1$ & $14 \cdot 8$ & $0 \cdot 1$ & $29 \cdot 7$ & $16 \cdot 1$ & $49 \cdot 3$ & $40 \cdot 6$ \\
\hline \multicolumn{13}{|l|}{ Single parenting } \\
\hline No & $1581^{*}$ & 7 & $53 \cdot 7$ & $0 \cdot 1$ & $31 \cdot 4$ & $0 \cdot 1$ & 14.5 & $0 \cdot 1$ & $16 \cdot 2$ & $16 \cdot 0^{*}$ & $48 \cdot 0$ & $38 \cdot 0^{*}$ \\
\hline Yes & 1628 & 18 & $54 \cdot 1$ & $0 \cdot 2$ & $31 \cdot 1$ & $0 \cdot 2$ & 14.5 & $0 \cdot 1$ & $19 \cdot \overline{1}$ & $22 \cdot 5$ & $45 \cdot 9$ & $45 \cdot 7$ \\
\hline \multicolumn{13}{|l|}{ Annual income (\$CAN) } \\
\hline$<20000$ & 1596 & 21 & $53 \cdot 9$ & 0.3 & $31 \cdot 2$ & $0 \cdot 2$ & $14 \cdot 5^{\star}$ & $0 \cdot 1$ & $13 \cdot 3^{*}$ & $14 \cdot 1$ & $39 \cdot 4$ & $47 \cdot 7$ \\
\hline $20000-39999$ & 1604 & 15 & $53 \cdot 8$ & 0.2 & $31 \cdot 5$ & $0 \cdot 1$ & $14 \cdot 3$ & $0 \cdot 1$ & $13 \cdot 1$ & $20 \cdot 9$ & $46 \cdot 5$ & $36 \cdot 9$ \\
\hline $40000-59999$ & 1600 & 13 & $53 \cdot 7$ & $0 \cdot 2$ & $31 \cdot 6$ & $0 \cdot 1$ & $14 \cdot 3$ & $0 \cdot 1$ & $14 \cdot 0$ & $16 \cdot 0$ & $47 \cdot 8$ & $39 \cdot 1$ \\
\hline$\geq 60000$ & 1568 & 11 & $53 \cdot 8$ & $0 \cdot 1$ & $31 \cdot 2$ & $0 \cdot 1$ & $14 \cdot 7$ & $0 \cdot 1$ & $21 \cdot 6$ & $16 \cdot 1$ & $50 \cdot 7$ & $38 \cdot 8$ \\
\hline \multicolumn{13}{|l|}{ Income level } \\
\hline Sufficient & $1579^{*}$ & 8 & $53 \cdot 7$ & $0 \cdot 1$ & $31 \cdot 4$ & $0 \cdot 1$ & $14 \cdot 5$ & $0 \cdot 1$ & $17 \cdot 1$ & $16 \cdot 0^{*}$ & $49 \cdot 6^{*}$ & $38 \cdot 0$ \\
\hline Insufficient & 1613 & 19 & $53 \cdot 9$ & 0.3 & $31 \cdot 3$ & $0 \cdot 2$ & $14 \cdot 4$ & $0 \cdot 1$ & $17 \cdot 3$ & $24 \cdot 0$ & $38 \cdot 5$ & $41 \cdot 9$ \\
\hline \multirow{2}{*}{\multicolumn{13}{|c|}{ Mother's BMI $\left(\mathrm{kg} / \mathrm{m}^{2}\right)$}} \\
\hline & & & & & & & & & & & & \\
\hline$<18.5$ & 1593 & 27 & $54 \cdot 2$ & 0.4 & $31 \cdot 0$ & 0.2 & $14 \cdot 5$ & $0 \cdot 2$ & $22 \cdot 9^{*}$ & $17 \cdot 4$ & $44 \cdot 8$ & $40 \cdot 7$ \\
\hline $18 \cdot 5-24.9$ & 1587 & 9 & $53 \cdot 7$ & $0 \cdot 1$ & $31 \cdot 4$ & $0 \cdot 1$ & $14 \cdot 6$ & $0 \cdot 1$ & $17 \cdot 5$ & $15 \cdot 2$ & $48 \cdot 3$ & $38 \cdot 1$ \\
\hline $25 \cdot 0-29 \cdot 9$ & 1586 & 16 & $54 \cdot 0$ & 0.2 & $31 \cdot 3$ & 0.1 & 14.5 & $0 \cdot 1$ & $16 \cdot 9$ & $18 \cdot 7$ & $45 \cdot 4$ & $39 \cdot 4$ \\
\hline$\geq 30 \cdot 0$ & 1586 & 23 & $53 \cdot 9$ & $0 . \overline{3}$ & 31.5 & $0 \cdot 2$ & $14 \cdot 1$ & 0.2 & $6 \cdot 6$ & $22 \cdot 5$ & $47 \cdot 5$ & $40 \cdot 8$ \\
\hline \multicolumn{13}{|c|}{ Number of overweight/obese parents } \\
\hline 0 & 1583 & 11 & 53.9 & $0 \cdot 1$ & $31 \cdot 3$ & $0 \cdot 1$ & $14 \cdot 5$ & $0 \cdot 1$ & $19 \cdot 1$ & $16 \cdot 0$ & $47 \cdot 4$ & $37 \cdot 4$ \\
\hline 1 & 1585 & 10 & $53 \cdot 8$ & $0 \cdot 1$ & $31 \cdot 4$ & $0 \cdot 1$ & 14.5 & $0 \cdot 1$ & $15 \cdot 9$ & $16 \cdot 3$ & $48 \cdot 0$ & $38 \cdot 4$ \\
\hline 2 & 1596 & 18 & $53 \cdot 8$ & $0 \cdot 2$ & $31 \cdot 5$ & $0 \cdot 2$ & $14 \cdot 4$ & $0 \cdot 1$ & $13 \cdot 1$ & $18 \cdot 8$ & $45 \cdot 6$ & $42 \cdot 8$ \\
\hline
\end{tabular}

$\% \mathrm{E}$, percentage of energy.

*Statistically significant association between the characteristic and the dependent variable $(P$ value $\leq 0.05)$. 
Table 2 Adjusted mean energy and macronutrient intakes by different characteristics

\begin{tabular}{|c|c|c|c|c|c|c|c|c|}
\hline \multirow[b]{2}{*}{ Characteristic } & \multicolumn{2}{|c|}{ Energyt } & \multicolumn{2}{|c|}{ Carbohydratesł } & \multicolumn{2}{|c|}{ Total fats $\ddagger$} & \multicolumn{2}{|c|}{ Proteinsł } \\
\hline & kcal & SD & $\% \mathrm{E}$ & SD & $\% \mathrm{E}$ & SD & $\% \mathrm{E}$ & SD \\
\hline \multicolumn{9}{|l|}{ Child's sex } \\
\hline Girl & $1562^{*}$ & 39 & $53 \cdot 4$ & 0.5 & $31 \cdot 5$ & $0 \cdot 4$ & $14 \cdot 7$ & $0 \cdot 3$ \\
\hline Boy & 1690 & 38 & $53 \cdot 4$ & 0.5 & $31 \cdot 5$ & 0.4 & $14 \cdot 6$ & $0 \cdot 3$ \\
\hline \multicolumn{9}{|l|}{ Mother's immigrant status } \\
\hline Not immigrant & $1603^{*}$ & 38 & $53 \cdot 4$ & 0.5 & $31 \cdot 7^{*}$ & 0.4 & $14 \cdot 5^{*}$ & 0.3 \\
\hline Immigrant & 1649 & 41 & $53 \cdot 4$ & 0.5 & $31 \cdot 3$ & $0 \cdot 4$ & $14 \cdot 8$ & $0 \cdot 3$ \\
\hline \multicolumn{9}{|l|}{ Mother's education } \\
\hline No high-school diploma & 1656 & 41 & $53 \cdot 4$ & 0.6 & $31 \cdot 9^{*}$ & 0.4 & $14 \cdot 2^{\star}$ & 0.3 \\
\hline High-school diploma & 1605 & 40 & $53 \cdot 5$ & $0 \cdot 6$ & $31 \cdot 4$ & $0 \cdot 4$ & $14 \cdot 6$ & 0.3 \\
\hline College diploma & 1616 & 39 & $53 \cdot 3$ & 0.5 & $31 \cdot 4$ & 0.4 & $14 \cdot 8$ & $0 \cdot 3$ \\
\hline University diploma & 1627 & 40 & $53 \cdot 5$ & 0.5 & $31 \cdot 2$ & $0 \cdot 4$ & $15 \cdot 0$ & 0.3 \\
\hline \multicolumn{9}{|l|}{ Single parenting } \\
\hline No & 1612 & 38 & $53 \cdot 3$ & 0.5 & $31 \cdot 6$ & 0.4 & $14 \cdot 6$ & 0.3 \\
\hline Yes & 1639 & 41 & $53 \cdot 5$ & 0.6 & $31 \cdot 3$ & $0 \cdot 4$ & $14 \cdot 7$ & 0.3 \\
\hline \multicolumn{9}{|l|}{ Income level } \\
\hline Sufficient & 1606 & 39 & $53 \cdot 3$ & 0.5 & $31 \cdot 6$ & $0 \cdot 4$ & $14 \cdot 7$ & 0.3 \\
\hline Insufficient & 1610 & 40 & $53 \cdot 4$ & 0.5 & $31 \cdot 4$ & $0 \cdot 4$ & $14 \cdot 6$ & 0.3 \\
\hline Very insufficient & 1661 & 45 & $53 \cdot 4$ & 0.6 & $31 \cdot 4$ & $0 \cdot 4$ & $14 \cdot 6$ & 0.3 \\
\hline
\end{tabular}

$\% \mathrm{E}$, percentage of energy.

$1 \mathrm{kcal}=4 \cdot 184 \mathrm{~kJ}$

*Statistically significant association between the characteristic and the dependent variable $(P$ value $\leq 0.05)$

†Adjusted for child's sex, mother's immigrant status, mother's education, single parenting, income level and physical activity level.

$\ddagger$ Adjusted for child’s sex, mother's immigrant status, mother's education, single parenting, income level, and physical activity level, and carbohydrates, lipids and proteins as proportion of energy.

Table 3 Adjusted OR for attaining dietary recommendations for food group servings at 4 years of age by different characteristics

\begin{tabular}{|c|c|c|c|c|c|c|c|c|}
\hline \multirow[b]{3}{*}{ Characteristic } & \multirow{2}{*}{\multicolumn{2}{|c|}{$\begin{array}{c}\text { Fruit and vegetablest } \\
\geq 5 \text { servings }\end{array}$}} & \multirow{2}{*}{\multicolumn{2}{|c|}{$\begin{array}{c}\text { Grain products } \dagger \\
\geq 5 \text { servings }\end{array}$}} & \multirow{2}{*}{\multicolumn{2}{|c|}{$\begin{array}{l}\text { Milk productst } \\
\geq 2 \text { servings }\end{array}$}} & \multirow{2}{*}{\multicolumn{2}{|c|}{$\begin{array}{c}\text { Meat and alternativest } \\
\geq 2 \text { servings }\end{array}$}} \\
\hline & & & & & & & & \\
\hline & Adjusted OR & $95 \% \mathrm{Cl}$ & Adjusted OR & $95 \% \mathrm{Cl}$ & Adjusted OR & $95 \% \mathrm{Cl}$ & Adjusted OR & $95 \% \mathrm{Cl}$ \\
\hline \multicolumn{9}{|l|}{ Child's sex } \\
\hline Girl & $1 \cdot 0$ & Ref. & $1 \cdot 0$ & Ref. & $1 \cdot 0$ & Ref. & $1 \cdot 0$ & Ref. \\
\hline Boy & $1 \cdot 1$ & $0 \cdot 8,1 \cdot 5$ & $5 \cdot 0^{*}$ & $3 \cdot 3,7 \cdot 5$ & $0 \cdot 7^{*}$ & $0.5,0.9$ & $1 \cdot 9^{*}$ & $1 \cdot 5,2 \cdot 4$ \\
\hline \multicolumn{9}{|l|}{ Mother's immigrant status } \\
\hline Not immigrant & $2 \cdot 2^{*}$ & $1 \cdot 3,3 \cdot 7$ & $0 \cdot 4^{\star}$ & $0.2,0.6$ & $0 \cdot 7$ & $0 \cdot 5,1 \cdot 1$ & $1 \cdot 2$ & $0 \cdot 9,1 \cdot 7$ \\
\hline Immigrant & $1 \cdot 0$ & Ref. & $1 \cdot 0$ & Ref. & $1 \cdot 0$ & Ref. & $1 \cdot 0$ & Ref. \\
\hline \multicolumn{9}{|l|}{ Mother's education } \\
\hline No high-school diploma & $1 \cdot 0$ & Ref. & $1 \cdot 0$ & Ref. & $1 \cdot 0$ & Ref. & $1 \cdot 0$ & Ref. \\
\hline High-school diploma & $2 \cdot 0^{*}$ & $1 \cdot 0,3 \cdot 7$ & $1 \cdot 1$ & $0.6,1.9$ & $1 \cdot 6^{\star}$ & $1 \cdot 1,2 \cdot 4$ & $1 \cdot 3$ & $0.9,1.9$ \\
\hline College diploma & $2 \cdot 8^{*}$ & $1 \cdot 5,5 \cdot 0$ & $1 \cdot 4$ & $0 \cdot 8,2 \cdot 4$ & $1 \cdot 7^{\star}$ & $1 \cdot 2,2 \cdot 5$ & $1 \cdot 3$ & $0.9,1.9$ \\
\hline University diploma & $8 \cdot 5^{\star}$ & $4 \cdot 6,15 \cdot 4$ & $1 \cdot 1$ & $0 \cdot 6,2 \cdot 0$ & $1 \cdot 5^{\star}$ & $1 \cdot 0,2 \cdot 3$ & 1.5 & $1 \cdot 0,2 \cdot 2$ \\
\hline \multicolumn{9}{|l|}{ Single parenting } \\
\hline No & $1 \cdot 0$ & Ref. & $1 \cdot 0$ & Ref. & $1 \cdot 0$ & Ref. & $1 \cdot 0$ & Ref. \\
\hline Yes & $1 \cdot 3$ & $0 \cdot 8,1 \cdot 9$ & $1 \cdot 4$ & $0 \cdot 9,2 \cdot 3$ & $1 \cdot 0$ & $0 \cdot 7,1 \cdot 4$ & $1 \cdot 3$ & $0.9,1.8$ \\
\hline \multicolumn{9}{|l|}{ Income level } \\
\hline Sufficient & $1 \cdot 0$ & Ref. & $1 \cdot 0$ & Ref. & $1 \cdot 0$ & Ref. & $1 \cdot 0$ & Ref. \\
\hline Insufficient/very insufficient & $0 \cdot 8$ & $0 \cdot 6,1 \cdot 3$ & $0 \cdot 8$ & $0 \cdot 5,1 \cdot 4$ & $0 \cdot 6^{*}$ & $0 \cdot 4,0 \cdot 8$ & $1 \cdot 3$ & $0.9,1 \cdot 8$ \\
\hline
\end{tabular}

Ref., reference category.

${ }^{*}$ Statistically significant $\mathrm{OR}$ and $95 \% \mathrm{Cl}(P$ value $\leq 0.05)$.

†Adjusted for child's sex, mother's immigrant status, mother's education, single parenting, income level, energy and physical activity level.

to this population; energy intake is dependent upon children's level of physical activity, and this was documented through parental report and not directly measured $^{(23)}$. However, the observed levels of energy intake concur with values observed through the NHANES. Across the years 1999-2000, NHANES reported that children aged 3-5 years consumed a mean daily energy intake of $6786 \mathrm{~kJ}(1622 \mathrm{kcal})^{(30)}$. American figures (NHANES) and those reported in the present study are clearly higher than what is advised by the Nordic Nutrition Recommendations for children aged $2-5$ years, which stipulate a daily energy intake of $5293 \mathrm{~kJ}(1265 \mathrm{kcal})^{(31)}$. Using various dietary methodologies and sample sizes, a summary of European studies reported by Lambert et $a l^{(32)}$ allows for other comparisons. For instance, energy intakes for boys aged $4-6$ years are reported to range from $5293 \mathrm{~kJ}(1265 \mathrm{kcal}) / \mathrm{d}$ in the UK to $7694 \mathrm{~kJ}(1839 \mathrm{kcal}) / \mathrm{d}$ in Austria. Corresponding intakes for girls vary from $5096 \mathrm{~kJ}(1218 \mathrm{kcal}) / \mathrm{d}$ to $9590 \mathrm{~kJ}$ 
(2292 kcal)/d across these same countries. For 4-6-year-old boys, the proportion of energy intakes derived from carbohydrates is reported to vary from $44 \%$ in Greece to $56 \cdot 8 \%$ in Russia. As a percentage of total energy, the fat intakes of 4-6-year-old girls are also reported to vary from $35.5 \%$ in the UK to $41 \%$ in Greece, whereas protein intakes vary from $11.7 \%$ in Russia to $13.6 \%$ in the Netherlands. In the American survey (NHANES), $13 \cdot 2 \%$ of energy intake came from proteins, $55 \cdot 4 \%$ from carbohydrates and $32 \cdot 9 \%$ from fats in children under 6 years of age ${ }^{(8)}$. The results of the present study suggest that the contribution of protein to children's energy intakes exceeds levels reported in most European studies reviewed by Lambert et $a l^{(32)}$. On the contrary, intakes of fat, as a percentage of energy intake, appear to be lower in Quebec than in most European countries. However, total energy intake and the percentage of energy intake from carbohydrates in the present study are comparable to those of most studies.

The mean number of servings of foods consumed from each of the four essential food groups by children of this cohort closely approached the dietary recommendations made by Canada's Food Guide to Healthy Eating; however, $<2 \%$ of children actually met the dietary guidelines of all four food groups simultaneously (data not presented). Unlike the findings observed in the present study, a Spanish study of 1112 children aged 6-7 years found that a majority of children maintained the dietary recommendations made by the $\mathrm{USDA}^{(33)}$. Compared with findings observed in the USA through a study of children included in the CSFII, the mean number of servings of milk products consumed by children in the present study cohort was equal to the number of servings consumed by children in the CSFII, but was lower for servings of grain products and meat and alternatives ${ }^{(34)}$. Compared with results from the ALSPAC study, a cohort of 1026 children aged 1.5 years, the percentage of vegetable/fruit nonconsumers $(2 \cdot 5 \%)$ between studies is comparable ${ }^{(35)}$ (data not presented).

The present study indicates that mother's immigrant status, mother's level of education and sex of the child are especially central socio-economic and demographic factors that relate to children's food intakes. With regard to mother's immigrant status, the findings of the present study concur partially with a study from the Canadian province of Ontario where the immigrant population of adults is reported to consume less fat and more carbohydrates ${ }^{(36,37)}$. As Pomerleau et al. ${ }^{(36,37)}$ reported, the differences between the diets of children of immigrant mothers and children of non-immigrant mothers may reflect food consumption patterns of different countries of origin, which may also relate to food availability within those countries. For instance, many studies have reported that immigrants from South Asian countries have lower fat intakes than non-immigrants ${ }^{(14)}$. Since immigrants are often in a situation of cultural and dietary transition, various studies have examined the association between this transition and dietary patterns. For example, Renzaho et $a l .{ }^{(38)}$ recently reported that the maintenance of traditional cultural orientation among African migrant children (3-12-year-olds) to Australia was associated with lower rates of obesity and sedentary behaviours. Given that in the present study cohort only $2 \cdot 8 \%$ of mothers were from European countries whereas $11 \%$ originated from nonEuropean countries ${ }^{(24)}$, the results suggest that, in this population, immigrants may still be adhering to traditional diets that are high in grains. Children of immigrant mothers are also more likely to be raised in a lowincome family compared with children of Canadian-born mothers ${ }^{(39)}$, and this may explain why in the present study it was observed that children of immigrant mothers consumed less fruit and vegetables than did children of non-immigrant mothers. Some studies report that lowerincome families tend to consume fewer fruit and vegetables and less varied diets ${ }^{(40,41)}$. However, in the present study, income level was controlled for and the relationship between a mother's immigrant status and children's lower fruit and vegetable intake remained. Thus, it is possible that the dietary choices of new immigrants may be influenced by several other determinants, apart from income level and poverty, including culture, access to information, availability of healthy and acceptable foods and acculturation ${ }^{(42)}$.

With regard to the association between mother's level of education and children's food intake, our results are in accordance with findings from the British National Diet and Nutrition Study that analysed the diet of 1675 children aged $1.5-4.0$ years; this aforementioned study found that children of mothers with a low level of education and children from families where the head of the household had a manual occupation were less likely to meet the recommended guidelines for macronutrient intakes ${ }^{(43)}$. Most studies support a positive association between parental level of education and intakes of healthy foods ${ }^{(5,16,17)}$. Since recent studies ${ }^{(4)}$ have reported that different socioeconomic groups are largely familiar with nutritional recommendations, it may be hypothesized that nutritional recommendations (such as other medical recommendations regarding child care, smoking, etc.) may be valued differently in lower socio-economic groups. Furthermore, as nutritional recommendations are usually encouraged and advocated by medical professionals and individuals from higher socio-economic groups, such recommendations may be perceived by individuals from lower socio-economic groups as an attempt to impose a moral constraint or 'an attempt to impose a control on their bodies or the ones of their children' ${ }^{\text {(4) }}$, as such individuals may be more concerned with meeting daily needs or maintaining other values and pleasures of life. Further research is needed to examine this hypothesis.

Finally, the findings of the present study on the association between the sex of a child and food intake contrast with findings from the ALSPAC study, which found 
that, among 7-year-old children, girls ate more fruit and vegetables in comparison with boys ${ }^{(44)}$. However, as was observed in the present study, being a boy was associated with a higher intake of grain products. It is possible that, as was found in the ALSPAC study, boys may be consuming greater quantities of breakfast cereals in comparison with girls, who appear to be more likely to skip breakfast than boys ${ }^{(45)}$. However, this hypothesis remains to be tested. With regard to fruit and vegetable intakes, in 1998 the CSFII survey found that boys consumed more of all foods except fruit and vegetables ${ }^{(7)}$. However, using data from the 1999-2002 NHANES, Lorson et al. ${ }^{(46)}$ recently reported that among children aged 2-18 years of age boys consumed significantly more vegetables than did girls. As boys also consumed significantly more French fries than did girls (the leading source of vegetables in the study reported by Lorson et $a l^{(46)}$ ), it should not be automatically assumed that boys consumed more dark green or orange vegetables than did girls*. At this pre-school age, children's preferences and differences between boys and girls are certainly influenced by the food environment that the parent provides. In a study on 3-4-year-old children, Johnson and $\operatorname{Birch}^{(47)}$ reported differences in how boys and girls are parented regarding food and eating practices. Their results showed that 'restrained' mothers attempted to restrain their daughters and not their sons. These results indicate that differential pressure for thinness between boys and girls begins during the pre-school period. These differences in parental child-feeding practices may also explain why boys were found to consume more energy than were girls in the present study. Analyses conducted by Dubois and Girard $^{(48)}$ using data from the QLSCD showed that a higher proportion of mothers overestimated weights for boys than for girls. The authors hypothesized that mothers of young children may be influenced by social desirability and have different standards of what is acceptable in weight for boys and girls. It is also possible that boys' energy needs are higher than that of girls because of larger body height and weight. In fact, Desrosiers et $a l^{(24)}$, who also used data from the QLSCD, reported sex differences in mean weight and height even at the age of 4 years: $17 \cdot 2 \mathrm{~kg}$ for boys $v .16 \cdot 6 \mathrm{~kg}$ for girls; $104 \mathrm{~cm}$ for boys $v$. $102 \cdot 8$ for girls. Finally, the fact that children's level of physical activity was incorporated among the control variables is limited by the reported rather than measured nature of this variable.

\section{Strengths, limitations and conclusion}

The results of the present study should be considered in the context of its strengths and limitations. The large

\footnotetext{
* For vegetables classification, see MyPyramid on the USDA website: www.mypyramid.gov
}

representative population-based sample and the high response rate $(85 \%)$ obtained are the most important strengths of the present study. Although the $24 \mathrm{~h}$ recall method is considered to be one of the best measures used to estimate dietary intake, it is known that this method may be biased by a high proportion of underreporters ${ }^{(49)}$. For instance, there is an increased tendency among obese parents to under-report children's dietary intakes in comparison with non-obese parents ${ }^{(50)}$. Some studies also report that snack foods are commonly underreported $^{(51)}$. To avoid these biases, O'Connor et al. ${ }^{(52)}$ recommend that children aged 6-9 years complete three $24 \mathrm{~h}$ recall interviews to minimize errors associated with under-reporting. Although we did not reach this recommended objective, energy, macronutrient and food consumption patterns were derived from a $24 \mathrm{~h}$ dietary recall interview conducted by trained nutritionists and a second $24 \mathrm{~h}$ dietary recall was administered to $50 \%$ of the sample to assess for inter- and intra-child variability in the consumption of energy and macronutrients. The absence of information on parental food intake is a noteworthy limitation as it has been shown that parental fruit and vegetable intake is a strong predictor of children's fruit and vegetable intake ${ }^{(53)}$. However, given that diet quality is tributary to socio-economic factors such as those measured in the present study ${ }^{(54)}$, it is assumed that the lack of this information has a minimal impact on the results. Another limitation to the study results is the absence of information on children's weight and height.

Overall, the present study revealed that even for preschool children dietary intakes were associated with socio-economic and demographic factors, most notably with mother's level of education, immigrant status and sex of the child. Children of mothers with no high-school diploma consumed fewer proteins, more fats (by percentage of total energy intake) and were less likely to consume the recommended servings of fruit and vegetables in comparison with children of mothers with a higher level of education. Children of immigrant mothers consumed significantly more energy but less fruit and vegetables than did children of non-immigrant mothers. The present study also revealed that the odds for consuming the recommended servings of grain products and meat and alternatives were higher in boys than in girls, whereas for milk products the odds were higher in girls than in boys. Reducing diet-related disparities and promoting healthy eating involve a complex interaction of factors. When efforts to improve the nutrition and health of young children are planned, these diet-related disparities need to be taken into account.

\section{Acknowledgements}

The research work of L.D. was supported by the Canada Research Chair Program. The present study has been 
partly financed by the Canadian Institute of Health Information, Population Health Initiative and by the Canadian Institute of Health Research. Analyses were performed using data from the Longitudinal Study of Child Development in Québec (LSCDQ) 1998-2010, conducted by Santé Québec, a division of the Institut de la Statistique du Québec, and funded by the Ministry of Health and Social Services of Québec. No conflict of interest is declared. L.D. is the director of the study (questionnaire development, data analysis, interpretation of the data, etc.); M.G. planned and performed the statistical data analysis; A.F., D.B. and M.P. contributed to literature review, content analysis and writing of the manuscript. All authors have seen and approved the manuscript and have met all requirements for authorship.

\section{References}

1. Halbwachs M (1938) Esquisse d'une Psychologie des Classes Sociales. Paris: Presses Universitaires de France.

2. Régnier F (2009) Obésité, goûts et consommation. Intégration des normes d'alimentation et appartenance sociale. Rev Fr Sociol 50, 747-773.

3. Bourdieu P (1984) Distinction: A Social Critique of the Judgement of Taste. Cambridge, MA: Harvard University Press.

4. Régnier F \& Masullo A (2008) Une Affaire de Goût? Réception et Mise en Pratique des Recommendations Nutritionnelles. Paris: INRA.

5. Roos G, Johansson L, Kasmel A et al. (2001) Disparities in vegetable and fruit consumption: European cases from the north to the south. Public Health Nutr 4, 35-43.

6. Taylor JP, Evers S \& McKenna M (2005) Determinants of healthy eating in children and youth. Can J Public Health/ Rev Can Sante Publique 96, Suppl. 3, S20-S26.

7. Wilkinson-Enns C, Mickle SJ \& Goldman JD (2002) Trends in food and nutrient intakes by children in the United States. Fam Econ Nutr Rev 14, 56-68.

8. National Centre for Health Statistics (2003) Dietary intake of ten key nutrients for public health, United States: 1999-2000. Adv Data 334, 1-4.

9. Kant AK \& Graubard BI (2003) Predictors of reported consumption of low-nutrient-density foods in a 24-h recall by 8-16 year old US children and adolescents. Appetite 41, 175-180.

10. Subar AF, Krebs-Smith SM, Cook A et al. (1998) Dietary sources of nutrients among US children, 1989-1991. Pediatrics 102, 913-923.

11. Troiano RP, Briefel RR, Carroll MD et al. (2000) Energy and fat intakes of children and adolescents in the United States: data from the National Health and Nutrition Examination Surveys. Am J Clin Nutr 72, Suppl. 5, 1343S-1353S.

12. Skinner JD, Carruth BR, Houck KS et al. (1999) Longitudinal study of nutrient and food intakes of white preschool children aged 24 to 60 months. J Am Diet Assoc 99, 1514-1521.

13. Rasmussen M, Krolner R, Klepp K-I et al. (2006) Determinants of fruit and vegetable consumption among children and adolescents: a review of the literature. Part I: quantitative studies. Int J Behav Nutr Phys Act 3, 22.

14. Kim KK, Yu ES, Liu WT et al. (1993) Nutritional status of Chinese-American, Korean-American, and JapaneseAmerican elderly. J Am Diet Assoc 93, 1416-1422.

15. Xie B, Gilliland FD, Li YF et al. (2003) Effects of ethnicity, family income, and education on dietary intake among adolescents. Prev Med 36, 30-40.

16. Sausenthaler S, Kompauer I, Mielck A et al. (2007) Impact of parental education and income inequality on children's food intake. Public Health Nutr 10, 24-33.
17. Serra-Majem L, Ribas L, Perez-Rodrigo C et al. (2002) Determinants of nutrient intake among children and adolescents: results from the enKid study. Ann Nutr Metab 46, 31-38

18. Kranz S \& Siega-Riz AM (2002) Sociodemographic determinants of added sugar intake in preschoolers 2 to 5 years old. J Pediatr 140, 667-672.

19. North K \& Emmett P (2000) Multivariate analysis of diet among three-year-old children and associations with sociodemographic characteristics. Eur J Clin Nutr 54, 73-80.

20. Nicklaus S, Boggio V et al. (2004) A prospective study of food preferences in childhood. Food Qual Prefer 15, 805-818.

21. Institute of Medicine (1998) Dietary Reference Intakes: A Risk Assessment Model for Establishing Upper Intake Levels for Nutrients. Washington, DC: National Academy Press.

22. Dubois L, Bédard B, Girard M et al. (2000) Etude Longitudinale du Développement des Enfants du Québec (ELDEQ 1998-2002). Les Nourrissons de 5 Mois. Québec: Institut de la Statistique du Québec.

23. Dubois L \& Girard M (2002) L'alimentation des Enfants d'Âge Préscolaire. Etude Longitudinale du Développement des Enfants du Québec (ELDEQ 1998-2002). Québec: Institut de la Statistique du Québec.

24. Desrosiers H, Dubois L, Bédard B et al. (2005) Enquête de Nutrition Auprès des Enfants Québecois de 4 Ans. Québec: Institut de la Statistique du Québec.

25. Liu K, Stamler J, Dyer A et al. (1978) Statistical methods to assess and minimize role of intra-individual variability in obscuring relationship between dietary lipids and serum cholesterol. J Chron Dis 31, 399-418.

26. Health Canada (2001) Canadian Nutrient File. Ottawa: Health Canada.

27. US Department of Agriculture (2004) Food and Nutrient Database for Dietary Studies, 1.0. 2004. Beltsville, MD: Agricultural Research Service, Food Surveys Research Group.

28. Cox B \& Cohen S (1985) Methodological Issues for Health Care Surveys. New York: Marcel Dekker.

29. Institute of Medicine (2002) Dietary Reference Intakes for Energy, Carbohydrate, Fiber, Fat, Fatty Acids, Cholesterol, Protein and Amino Acids. Washington, DC: National Academy Press.

30. Briefel RR \& Johnson CL (2004) Secular trends in dietary intake in the United States. Ann Rev Nutr 24, 401-431.

31. Nordic Council of Ministers (2004) Nordic Nutrition Recommendations 2004. Integrating Nutrition and Physical Activity. Copenhagen: NCM.

32. Lambert J, Agostoni C, Elmadfa I et al. (2004) Dietary intake and nutritional status of children and adolescents in Europe. Br J Nutr 92, Suppl. 2, S147-S211.

33. Royo-Bordonada MA, Gorgojo L, Martin-Moreno JM et al. (2003) Spanish children's diet: compliance with nutrient and food intake guidelines. Eur J Clin Nutr 57, 930-939.

34. Munoz KA, Krebs-Smith SM, Ballard-Barbash R et al. (1997) Food intakes of US children and adolescents compared with recommendations. Pediatrics 100, 323-329.

35. Cowin I \& Emmett P (2000) Diet in a group of 18-monthold children in South West England, and comparison with the results of a national survey. J Hum Nutr Diet 13, 87-100.

36. Pomerleau J, Ostbye T \& Bright-See E (1998) Place of birth and dietary intake in Ontario I. Energy, fat, cholesterol, carbohydrate, fiber, and alcohol. Prev Med 27, 32-40.

37. Pomerleau J, Ostbye T \& Bright-See E (1998) Place of birth and dietary intake in Ontario II. Protein and selected micronutrients. Prev Med 27, 41-49.

38. Renzaho AMN, Swinburn B \& Burns C (2008) Maintenance of traditional cultural orientation is associated with lower rates of obesity and sedentary behaviours among African migrant children to Australia. Int $J$ Obes (Lond) 32, 594-600. 
39. Statistics Canada (2003) The Rise in Low-Income Rates Among Immigrants in Canada. Ottawa: Statistics Canada.

40. Kirkpatrick S \& Tarasuk V (2003) The relationship between low income and household food expenditure patterns in Canada. Public Health Nutr 6, 89-97.

41. Rogers I \& Emmett P (2003) The effect of maternal smoking status, educational level and age on food and nutrient intakes in preschool children: results from the Avon Longitudinal Study of Parents and Children. Eur J Clin Nutr 57, 854-864.

42. Hyman I, Guruge S, Makarchuk MJ et al. (2002) Promotion of healthy eating among new immigrant women in Ontario. Can J Diet Pract Res 63, 125-129.

43. Watt RG, Dykes J \& Sheiham A (2001) Socio-economic determinants of selected dietary indicators in British preschool children. Public Health Nutr 4, 1229-1233.

44. Glynn L, Emmett P \& Rogers I (2005) Food and nutrient intakes of a population sample of 7 -year-old children in the south-west of England in 1999/2000 - what difference does gender make? J Hum Nutr Diet 18, 7-19.

45. Rampersaud GC, Pereira MA, Girard BL et al. (2005) Review - breakfast habits, nutritional status, body weight, and academic performance in children and adolescents. J Am Diet Assoc 105, 743-760.

46. Lorson BA, Melgar-Quinonez HR \& Taylor CA (2009) Correlates of fruit and vegetable intakes in US children. J Am Diet Assoc 109, 474-478.
47. Johnson SL \& Birch LL (1994) Parents and childrens adiposity and eating style. Pediatrics 94, 653-661.

48. Dubois L \& Girard M (2007) Accuracy of materinal reports of pre-schoolers' weights and heights as estimates of BMI values. Int J Epidemiol 36, 132-138.

49. Black AE, Goldberg GR, Jebb SA et al. (1991) Critical evaluation of energy-intake data using fundamental principles of energy physiology. 2. Evaluating the results of published surveys. Eur J Clin Nutr 45, 583-599.

50. Heitmann BL \& Lissner L (2005) Can adverse effects of dietary fat intake be overestimated as a consequence of dietary fat underreporting? Public Health Nutr 8, $1322-1327$.

51. Krebs-Smith SM, Graubard BI, Kahle LL et al. (2000) Low energy reporters vs others: a comparison of reported food intakes. Eur J Clin Nutr 54, 281-287.

52. O'Connor J, Ball EJ, Steinbeck KS et al. (2001) Comparison of total energy expenditure and energy intake in children aged 6-9 y. Am J Clin Nutr 74, 643-649.

53. Cooke LJ, Wardle J, Gibson EL et al. (2004) Demographic, familial and trait predictors of fruit and vegetable consumption by pre-school children. Public Health Nutr 7 , 295-302.

54. Northstone K \& Emmett P (2005) Multivariate analysis of diet in children at four and seven years of age and associations with socio-demographic characteristics. Eur J Clin Nutr 59, 751-760. 